\title{
POLITIK HUKUM PENGATURAN PENYELESAIAN PERSELISIHAN HASIL PEMILIHAN KEPALA DESA
}

\author{
Hussein Ahmad, Tunggul Anshari, \\ Setyo Widagdo, \\ Program Studi Magister Ilmu Hukum \\ Pasca Sarjana Fakultas Hukum Universitas Brawijaya \\ Email: hussein@student.ub.ac.id
}

\begin{abstract}
ABSTRAK
Pada jurnal ini, penulis mengangkat permasalahan mengenai politik hukum pengaturan penyelesaian perselisihan hasil pemilihan Kepala Desa. Konstitusi telah menyatakan Indonesia sebagai negara Hukum. Konsekuensi logis dari negara hukum adalah adanya separation of power. Teori pemisahan kekuasaan ini dikenal dengan trias politika. Kemudian konstitusi juga mengatur bahwa negara mengakui keberadaan masyarakat hukum adat (termasuk desa) beserta hak-hak tradisionalnya, termasuk hak asal usul. Pengakuan ini disebut dengan Asas Rekognisi. UU Desa manyatakan penyelesaian perselisihan hasil pemilihan Kepala Desa diselesaikan oleh Bupati dan Walikota. Menjadi pertanyaan apakah penyelesaian perselisihan hasil pemilihan Kepala Desa telah sesuai konstitusi khususnya hak asal usul dan teori trias politika?. Penelitian ini adalah penelitian yuridis normatif dengan pendekatan perundang-undangan, sejarah dan konsep. Hasil dari penelitian ini menyatakan bahwa politik hukum pengaturan penyelesaian perselisihan hasil pemilihan Kepala Desa tidak sesuai dengan konstitusi dan teori trias politika.
\end{abstract}

Kata Kunci: Politik Hukum, Pemilihan Kepala Desa, Trias Politika, Hak Asal Usul.

\begin{abstract}
ABSTRAK
In this journal, researcher raised issue about the legal politics of the dispute resolutions over the Village Heads election results. The State of Indonesia is a state based on the rule of law. The consequence of the rule of law is the existence of a "separation of power". Theory of separation of powers is also known as trias politica. The constitution also regulate that the state recognizes the existence of the homogeneity of societies with customary law (including village) along with their traditional rights, including the "asal-usul right". This recognition is called Recognition Principle. The Village Law (UU Desa) declared that dispute resolutions over the Village Heads election results to be solved by the Bupati and the Mayor. It is a question of whether the dispute resolution over the election result has been in accordance with the constitution, especially the "asal-usul right" and the theory of trias politica. This research is normative juridical research with statute aproach, historical aproach and conceptual aproach. The result of this research indicates that the legal politics of the dispute resolutions over the Village Heads election results is not in accordance with constitution and trias politica theory.
\end{abstract}

Key words: Legal Politics, Village Heads Election, Trias Politica, Asal-Usul Rights. 


\section{Latar Belakang}

Konstitusi Indonesia menegaskan bahwa Indonesia adalah negara hukum

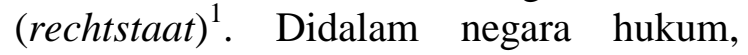
hukum an sich merupakan guidance bagi setiap tindakan atau perbuatan yang dilakukan maupun tidak dilakukan didalam wilayah negara hukum tersebut. Menurut Friedrich Julius Stahl sebuah negara hukum setidak-tidaknya harus mempunyai beberapa ciri, yakni terdapat perlindungan terhadap Hak Asasi Manusia (HAM), terdapat pemisahan atau pembagian kekuasaan (separation of power or distribution of power), dan adanya pemerintahan yang berdasarkan peraturanperaturan (wetmatigheid van bestuur), serta adanya peradilan administrasi yang bebas dalam perselisihan. ${ }^{2}$

Tidak adanya separation of power menyebabkan kekuasaan yang absolut. Hal ini menyebabkan tidak adanya checks and balances. Kondisi yang demikian menyebabkan kesewenang-wenangan merajalela. Oleh karena itulah ia berpendapat bahwa negara harus dijalankan dengan adanya pemisahan kekuasaan diantaranya. Sehingga tidak ada satupun orang ataupun lembaga memiliki kekuasaan yang absolut. $^{3}$

Konstitusi Indonesia juga menegaskan bahwa Indonesia adalah negara kesatuan yang berbentuk republik, disebut dengan Negara Kesatuan Republik Indonesia. Secara konstitusional Negara Kesatuan Republik Indonesia dibagi atas beberapa daerah provinsi yang mana daerah provinsi tersebut dibagi atas kabupaten atau kota yang mana dalam hal penyelenggaraan urusan pemerintahnya

${ }^{1}$ Lihat Pasal 1 Ayat (3) UUD NRI 1945.

2 Mahfud MD, Hukum dan Pilar-pilar Demokrasi, (Yogyakarta: Gama Media, 1999), hlm. 24.

Friedrich Julius Stahl, Siebzehn parlamentarische Reden und drei Vorträge : Seventeen Parliamentary Speeches and Three Lectures, (Berlin: Wilhelm Hertz,1862), hlm.. 2736. dilaksankan berdasarkan asas otonomi dan tugas pembantuan. ${ }^{4}$ Secara berkelanjutan kabupaten dan kota itu memiliki satuansatuan pemerintahan dibawahnya seperti kecamatan dan kelurahan. Di beberapa daerah juga terdapat pemerintahan Desa sebagai satuan pemerintahan dalam lingkup Desa.

Desa sebagai entitas pemerintahan yang paling kecil dalam kerangka bernegara ditegaskan eksistesinya dengan terbitnya Undang-Undang No. 6 Tahun 2014 tentang Desa (UU Desa). ${ }^{5}$ Terbitnya UU Desa ini tidak hanya memberikan perubahan pengaturan tetapi juga memberikan perubahan paradigma tentang Desa yang semula dipandang hanya menjadi perpanjangan tangan kabupaten atau kota menjadi sebuah kesatuan masyarakat yang otonom dan memiliki hak serta wewenang untuk mengatur dan mengurusi wilayahnya sendiri. ${ }^{6}$ Konsekuensi logis dari wewenang untuk mengatur dan mengurusi wilayah tersebut adalah Desa memiliki penyelenggara pemerintahannya sendiri sebagaimana sebuah pemerintahan pada umumnya. Oleh karena itu Pasal 1 Angka 3 UU Desa mengamanatkan adanya penyelenggara pemerintahan Desa yakni dipimpin Kepala Desa dan dibantu oleh perangkat Desa:

"Pemerintah Desa yang di maksud adalah Kepala Desa atau yang disebut dengan nama lain dibantu perangkat Desa sebagai unsur penyelenggara Pemerintahan Desa”.

Seiring dengan perkembangan paham demokrasi yang berkembang di Indonesia, pemilihan Kepala Desa sudah menjadi sebuah kebutuhan. Suksesi kepemimpinan berdasarkan garis keturunan sebagaimana lazim di masa lalu

\footnotetext{
${ }^{4}$ Lihat pasal 18 Ayat 1 dan 2 UUD NRI 1945

5 Lembaran Negara Republik Indonesia Tahun 2014 Nomor 7. Tambahan Lembaran Negara Nomor 5495

${ }^{6}$ Lihat pasal 1Angka 1 dan pasal $18 \mathrm{UU}$

Desa

${ }^{7}$ Lihat pasal 1 Angka 3 UU Desa
} 
menjadi tidak relevan lagi. Demokrasi yang mensyaratkan diberikannya kesempatan bagi setiap orang untuk memimpin menjadi salah satu agenda social engineering didalam UU Desa. Maka, didalam UU Desa masa jabatan Kepala Desa dibatasi hingga 6 (enam) tahun sejak dilantiknya Kepala Desa oleh Bupati atau Walikota. ${ }^{8}$ Adapun dalam hal pergantian Kepala Desa dilakukan dengan cara pemilihan Kepala Desa secara langsung. ${ }^{9}$

Pemilihan Kepala Desa, sebagaimana pemilihan-pemilihan lainnya sudah tentu menjadi arena pertarungan politik para calon. Hal ini dapat dipahami karena kewenangan yang dimiliki oleh Kepala Desa cukup besar. Kewenangan yang besar inilah yang menyebabkan banyak orang berlomba-lomba menjadi Kepala Desa. Hal ini secara praxis dapat berdampak baik bagi pendewasaan politik dan sarana pemahaman demokrasi yang baik bagi masyarakat Desa. Namun, dinamika politik dan demokrasi tersebut juga dapat melahirkan dampak yang buruk bagi Desa itu sendiri. Civil Society yang belum kuat di Desa dapat berdampak pemahaman politik dan demokrasi yang salah. ${ }^{10}$ Hal itu dapat dilihat dalam praktikpraktik money politic, penyalahgunaan wewenang, hingga kecurangan hasil pemilihan Kepala Desa. Dapat dipastikan pemilihan Kepala Desa dikemudian hari dapat menimbulkan perselisihan atas hasil pemilihan yang dilakukan.

Potensi perselisihan ini telah diantisipasi oleh pembentuk UU Desa dengan memberikan kesempatan para pihak untuk menggugat hasil pemilihan tersebut. Dalam hal terjadi perselisihan

${ }^{8}$ Lihat Pasal 39 UU Desa
${ }^{9}$ Lihat Pasal 34 UU Desa
${ }^{10}$ Muhammad As Hikam, Civil Society, Negara, dan Gerakan Kaum Muda, pengantar dalam buku Menuju Masyarakt Madani, Anas Urbaningrum, (Jakarta: Penerbit Yarsif Watampone, 1997). hasil pemilihan Kepala Desa, UU Desa menyatakan lembaga yang berwenang dalam penyelesaian perselisihan hasil pemilihan Kepala Desa adalah Bupati atau Walikota, yakni pada Pasal 37 Ayat (6) yang berbunyi:

"dalam hal terjadi perselisihan hasil Pemilihan Kepala Desa, Bupati/Walikota wajib menyelesaikan perselisihan dalam jangka waktu sebagaimana dimaksud dalam Ayat (5)"

Secara berkelanjutan konstitusi mengatur bahwa negara mengakui dan menghormati masyarakat adat dan hak-hak tradisionalnya. Konsekuensi logis dari pengakuan terhadap hak-hak tradisional itu adalah negara juga mengakui hak asal-usul sebagai hak yang melekat pada masyarakat adat. Dalam Pasal 18B Ayat (2) UUD NRI Tahun 1945 diatur:

"Negara mengakui dan menghormati kesatuan-kesatuan masyarakat hukum adat beserta hak-hak tradisionalnya sepanjang masih hidup dan sesuai dengan perkembangan masyarakat dan prinsip Negara Kesatuan Republik Indonesia, yang diatur dalam undang-undang."

Konsekuensi logis dari pengaturan tersebut adalah, Desa sebagai tempat hidupnya masyarakat adat, dalam hal pengaturan tidak bisa mengenyampingkan hak-hak tradisioal yang melekat padanya, artinya segala pengaturan harus mengakui hak seperti hak asal usul Desa. (asas rekognisi).

Hal inilah yang kemudian menjadi pertanyaan apakah pengaturan lembaga Bupati/Walikota sebagai lembaga yang berwenang menyelesaikan perselisihan hasil pemilihan Kepala Desa. telah sesuai dengan konstitusi khususnya amanat pengakuan terhadap hak asal-usul Desa.

Kemudian secara yuridis, keberadaan Bupati atau Walikota di Indonesia merupakan cabang kekuasaan eksekutif. Pengaturan ini dinilai tidak konsisten dengan teori trias politika yang memisahkan urusan pemerintahan dengan 
urusan peradilan. Teori trias politika mensyaratkan kekuasan dibagi atas eksekutif, legislatif dan yudikatif, sehingga penunjukkan Bupati atau Walikota sebagai lembaga yang menyelesaikan sengketa tidaklah lazim. Hal ini dikarenakan terkait permasalahan-permasalahan hukum lazimnya merupakan kewenangan absolut kekuasaan peradilan. UU No. 48 tahun 2009 tentang Kekuasaan Kehakiman (UU Kekusaaan Kehakiman) juga telah mengaskan bahwa kekuasaan yudikatif atau dalam UU Kekuasaan Kehakiman disebut dengan kekuasaan kehakiman adalah "Kekuasaan yang merdeka untuk menyelenggarakan peradilan guna menegakkan hukum". 11

Berangkat dari uraian diatas maka dirumuskan masalah sebagai beriku: a. Apakah politik hukum pengaturan penyelesaian perselisihan hasil pemilihan Kepala Desa menurut UU No. 6 Tahun 2014 tentang Desa konsisten dengan Undang Undang Dasar Negara Republik Indonesia Tahun 1945 ?. Dan b. Apakah politik hukum pengaturan penyelesaian perselisihan hasil pemilihan Kepala Desa menurut UU No. 6 Tahun 2014 tentang Desa sesuai dengan teori trias politika?.

Penelitian ini menggunakan metode penelitian Yuridis Normatif dengan pendekatan perundang-undangan (statue approach), pendekatan konsep (conceptual approach) dan pendekatan sejarah (historical approach)

\section{Pembahasan}

\section{A. Politik hukum pengaturan penyelesaian perselisihan hasil pemilihan Kepala Desa menurut UU}

11 Lembaran Negara Republik Indonesia Tahun 2009 Nomor 157. Pasal 1 Angka 1 UU Kekuasaan Kehakiman : Kekuasaan Kehakiman adalah kekuasaan negara yang merdeka untuk menyelenggarakan peradilan guna menegakkan hukum dan keadilan berdasarkan Pancasila dan Undang-Undang Dasar Negara Republik Indonesia Tahun 1945, demi terselenggaranya Negara Hukum Republik Indonesia.

\section{No. 6 Tahun 2014 tentang Desa konsisten dengan Undang Undang Dasar Negara Republik Indonesia Tahun 1945.}

Salah satu tujuan UU Desa sebagaimana dijelaskan dalam penjelasan UU Desa yakni memberikan pengakuan dan penghormatan atas Desa dengan keberagamannya sebelum dan sesudah terbentuknya Negara Kesatuan Republik Indonesia. $^{12} \mathrm{Hal}$ ini kemudian dikenal dengan istilah asas rekognisi.

Asas rekognisi merujuk pada arti yaitu pengakuan terhadap asal usul. $^{13}$ Dalam diskursus asas rekognisi kemudian dikenal adanya hak asal usul yang dimiliki oleh Desa. Penjelasan Pasal 18 UU Desa menyatakan yang dimaksud dengan hak asal usul adalah:

\section{Pasal 18}

"Yang dimaksud dengan "hak asal usul dan adat istiadat Desa" adalah hak yang masih hidup dan sesuai dengan perkembangan kehidupan masyarakat dan prinsip Negara Kesatuan Republik Indonesia.."

Hak asal usul merupakan salah satu hak yang dimaksud Pasal 18B Ayat (2) UUD NRI Tahun 1945 yaitu : ${ }^{14}$

\section{Pasal 18B Ayat (2)}

"Negara mengakui dan menghormati kesatuan-kesatuan masyarakat hukum adat beserta hak-hak tradisionalnya sepanjang masih hidup dan sesuai dengan perkembangan masyarakat dan prinsip Negara Kesatuan Republik Indonesia, yang diatur dalam undang-undang."

Secara implisit frasa “... mengakui dan menghormati masyarakat hukum adat

12 Lihat Tujuan dan Asas Pengaturan Penjelasan atas Undang-Undang Republik Indonesia Nomor 6 Tahun 2014 tentang Desa.

13 Ibid.,

14 Lihat UUD NRI Tahun 1945, Pasal 18B Ayat 2 
beserta hak-hak tradisional.. " dapat dimaknai sebagai pengakuan terhadap hakhak yang melekat pada Desa termasuk salah satunya hak asal usul. Dalam paripurna amandemen UUD 1945 menanggapi hal ini, Bagir Manan menjelaskan: ${ }^{15}$

"di samping hak ulayat masih ada hak-hak lain, sehingga kita perluweskan jadi hakhak tradisional sehingga hak ulayat, hak adat lainnya, hak numpang karang, hak macam-macam itu kalau ada, itu sehingga kita luweskan ke sana"

Maka dari itu dapat dikatakan bahwa hak asal-usul merupakan salah satu hal yang dimaksudkan Pasal 18B Ayat 2 UUD NRI Tahun 1945 dengan hak-hak tradisionalnya. Jika merujuk pada penjelasan Bagir Manan, tidak mungkin menyebut satu persatu hak-hak tradisional (termasuk hak asal-usul) di dalam konstitusi karena jumlahnya yang sangat banyak tidak dapat dimuat di dalam rumusan konstitusi sehingga diperluweskan dengan penggunaan kata yang lebih luwes yakni hak-hak tradisional.

Pengakuan terhadap hak asal usul Desa juga dapat ditemukan didalam rumusan konstitusi UUD 1945 sebelum amandemen, yakni dapat ditemukan pada Pasal 18, yang mengatur sebagai berikut :

Pasal 18

"Pembagian daerah Indonesia atas daerah besar dan kecil, dengan bentuk susunan pemerintahanannya ditetapkan dengan undang-undang, dengan memandang dan mengingati dasar permusyawaratan dalam sistem pemerintahan negara, dan hak-hak asal-usul dalam daerah-daerah yang bersifat istimewa"

\section{Penjelasan Pasal 18}

Dalam territoir Negara Indonesia terdapat lebih kurang 250

\footnotetext{
${ }^{15}$ Mahkamah Konstitusi, Op.Cit, hlm. 283.
}

zelfbesturendelandchappen dan volksgemeenschappen, seperti Desa di Jawa dan Bali, negeri di Minangkabau, dusun dan marga di Palembang dan sebagainya. Daerah-daerah itu mempunyai susunan asli, dan oleh karenanya - 48 dapat dianggap sebagai daerah yang bersifat istimewa. Negara Republik Indonesia menghormati kedudukan daerahdaerah istimewa tersebut dan segala peraturan negara yang mengenai daerah daerah itu akan mengingati hak-hak asalusul daerah tersebut.

Di dalam frasa "Negara Republik Indonesia menghormati kedudukan daerahdaerah istimewa tersebut dan segala peraturan negara yang mengenai daerahdaerah itu akan mengingati hak asal usul daerah tersebut", negara tengah memberikan pengakuan terhadap hak asalusul Desa. Frasa "mengingati” berarti sama dengan tidak mengabaikan keberadaan hak asal usul yang dimiliki Desa an sich. Dengan kata lain segala pengaturan mengenai daerah istimewa itu (termasuk Desa) tidaklah boleh mengabaikan hak asal usul. Dengan demikian menurut Pasal 18 ini Indonesia dibagi atas daerah besar dan kecil yang mana dalam hal pembentukkannya mengingati hak asal usul serta keistimewaannya, yang mana memiliki susunan asli dan oleh karena itu bersifat istimewa sehingga negara harus menghormati dan segala pengaturan harus sesuai dengan hak asal-usul daerah tersebut.

Terhadap istilah hak asal-usul Sujamto berpendapat bahwa yang dimaksud dengan hak asal usul menyangkut antara lain: ${ }^{16}$

1. Hak asal usul yang menyangkut struktur kelembagaan. Ini adalah yang tersirat dari kata-kata "susunan asli".

16 Sujamto, Daerah Istimewa Dalam Negara Kesatuan Republik Indonesia, (Jakarta : Bina Aksara, 1984), hlm. 14 
2. Hak asal usul yang menyangkut ketentuan dan prosedur tentang pengangkatan dan pemberhentian pemimpin.

3. Hak asal usul yang menyangkut penyelenggaraan urusan-urusan pemerintahan terutama yang berhubungan dengan penyelenggaraan dan pembebanan terhadap masyarakat.

Maka jelaslah sebetulnya UUD NRI Tahun 1945 mengamantakan penghormatan terhadap hak asal-usul yang dimiliki oleh Desa, dan oleh karena itu segala pengaturan tidak boleh bertentangan dengan hak asal-usul. Bahwa Desa telah ada terlebih dahulu dari NKRI dan oleh karena itu negara menghormati Desa yang memiliki kekhasannya untuk mengurus urusannya sendiri, dimana secara tradisional Desa mampu dan telah melakukan suksesi kepemimpinan. Hal ini sesuai dengan pendapat Sujamto yang mengatakan bahwa, "Hak asal usul yang menyangkut ketentuan dan prosedur tentang pengangkatan dan pemberhentian pemimpin.". Merujuk pada pendapat Sujamto itu maka seharusnya penyelesaian perselisihan hasil pemilihan Kepala Desa diberikan sepenuhnya kepada Desa atau masyarakat Desa, alih-alih diselesaikan oleh Bupati atau Walikota.

Penyelesaian perselisihan hasil pemilihan Kepala Desa seharusnya bebas dari campur tangan pemerintah dalam hal ini Bupati atau Walikota. Hal ini konsekuen dengan amanat UUD NRI Tahung 1945 yang menegaskan bahwa Desa memiliki hak asal usul. Pasal 18 UUD NRI Tahun 1945 yang menyatakan bahwa frasa “... mengakui dan menghotmati masyarakat hukum adat beserta hak-hak tradisional.. " berarti dalah hal mengatur penyelesaian perselisihan hasil pemilihan Kepala Desa maka negara tidak boleh mengabaikan hak asal usul.

$$
\text { Berkaca pada pengaturan }
$$
penyelesaian perselisihan hasil pemilihan
Kepala Desa yang diselesaikan oleh Bupati atau Walikota maka terang bahwa negara telah mengabaikan hak asal usul. Artinya pengaturan penyelesaian perselisihan hasil pemilihan Kepala Desa yakni diselesaikan oleh Bupati atau Walikota tidak konsisten dengan UUD NRI Tahun 1945 khususnya tidak konsisten dengan Pasal 18 B Ayat (2).

B. Politik hukum pengaturan penyelesaian perselisihan hasil pemilihan Kepala Desa menurut UU No. 6 Tahun 2014 tentang Desa sesuai dengan teori trias politika.

Dalam teori kontrak sosial, negara merupakan kesepakatan diantara rakyat untuk mengurusi urusan-urusan rakyat karena dilandasi rasa saling membutuhkan. ${ }^{17}$ Untuk mengurusi urusanurusan itu pemerintah diberikan wewenang atas sesuatu atau wewenang untuk menentukan sesuatu. Wewenang ini disebut kekuasaan. ${ }^{18}$ Namun kemudian kekuasaan yang bertumpuk pada satu kelompok atau satu orang saja maka akan melahirkan penyelewengan kekuasaan. Hal ini sesuai dengan ungkapan Lord Acton, "power tends to corrupt, but absolute power corrupts absolutely" yang maksudnya manusia yang mempunyai kekuasaan cenderung menyalah-gunakan (penyelewengan), tetapi manusia yang mempunyai kekuasaan tak terbatas pasti akan menyalahgunakannya. ${ }^{19}$ Oleh karena itu, kekuasaan harus dibatasi dan dibagi menjadi cabang-cabang kekuasaan. Dalam hal ini, yang dapat dianggap paling berpengaruh pemikirannya dalam mengadakan pembedaan fungsi-fungsi

17 Jean-Jacques Rousseau, “Du Contract Social", Terjemahan Rahayu Sutiati Hidayat dan Ida Sundari Husen, (Jakarta, Dian Rakyat, 2010), hlm. 17 dan 25.

18 Kaelan, PendidikanKewarganegaraan Untuk Perguruan Tinggi”, (Yogyakarta: Paradigma, 2010), hlm. 78.

19 Widayati, Rekonstruksi Kedudukan TAP MPR Dalam Sistem Ketatanegaraan, (Yogyakarta: Genta Publishing, 2015), hlm 69. 
kekuasaan itu adalah Montesquieu dengan teori trias politica-nya. ${ }^{20}$

Menurut Montesquieu dalam bukunya “L'Esprit des Lois" (1748), yang mengikuti jalan pikiran John Locke membagi kekuasaan negara dalam tiga cabang, yaitu; Pertama, kekuasaan legislatif sebagai pembuat undang-undang; Kedua, kekuasaan eksekutif yang melaksanakan; dan Ketiga, kekuasaan untuk menghakimi atau yudikatif. Dari klasifikasi Montesquieu inilah dikenal pemisahan kekuasaan. ${ }^{21}$ Montesquieu menilai bahwa dengan struktur pemerintahan tersebut dengan sumber wewenang yang berbeda-beda untuk masing-masing, ia melihat manfaatnya bagi kelestarian kebebasan individu. ${ }^{22}$

Menurut Montesquieu, manakala kekuasaan legislatif bergabung dengan kekuasaan eksekutif dalam diri satu orang atau dalam sebuah lembaga pemerintahan, maka tidak akan ada kebebasan, karena orang dapat merasa takut bahwa raja yang sama atau senat yang sama yang membuat undang-undang kejam itu akan melaksanakannya dengan kejam pula. Juga tidak ada kebebasan jika kekuasaan kehakiman tidak dipisahkan dari kekuasaan legislatif dan dari kekuasaan eksekutif. Kalau kekuasaan pengadilan itu digabungkan dengan kekuasaan legislatif, maka kekuasaan atas hidup dan kebebasan para warga negara akan menjadi semenamena, sebab hakimnya akan menjadi pembuat undang-undang.

Seandainya, kekuasaan pengadilan itu disatukan dengan kekuasaan eksekutif, maka hakim tersebut dapat memiliki kekuasaan seorang penindas pula. Semua bentuk kebebasan akan hilang seandainya

20 Jimly Asshiddiqie, Pengantar Ilmu Hukum Tata Negara, (Jakarta: PT. Rajagrafindo Persada, 2009), hlm. 282.

${ }^{21}$ Ibid., hlm. 283.

22 Charles De Montesqiue, the spirit of Laws, dalam buku Diane Revitch \& Abigail Thernstrom (ed), Demokrasi Klasik dan modern, (Jakarta: Obor, 2005), hlm. 80. orang yang sama atau lembaga orangorang terkemuka yang sama, entah terdiri dari para bangsawan, atau rakyat, menjalankan ketiga kekuasaan ini sekaligus; yaitu kekuasaan membuat undang-undang, kekuasaan menjalankan keputusan-keputusan publik, dan kekuasaan mengadili kejahatan atau perselisihan diantara orang-orang. ${ }^{23}$

Intinya Montesquieu menganggap bahwa kekuasaan negara tidak boleh tersentralisasi pada seorang penguasa yang berarti kekuasaan tidak boleh bersifat personal (personal power) atau hanya dikuasai oleh lembaga politik tertentu. Sebab bila demikian menurut Montesquieu akan mudah terjadi penyelewengan kekuasaan dan pelanggaran terhadap kebebasan sipil dan kebebasan politik rakyat. Gagasan Montesquieu ini sebenarnya upaya untuk menghindari terjadinya kekuasaan yang sentralistik yang menyebabkan lahirnya negara kekuasaan (absolute power). ${ }^{24}$.

Ajaran Montesquieu pada pokokya menginginkan keberadaan fungsi-fungsi legislatif, eksekutif, dan yudikatif tidak berada di dalam satu lembaga saja, melainkan dipisahkan menjadi 3 kekuasaan fungsi. Jika tidak demikian maka menurut Montesquieu kebebasan akan terancam. ${ }^{25}$ Berkenaan dengan pendapat Montesqiue, McDonald mengatakan, "The hearth of Montesquieu's theme was that where these three functions combined in the same person or body of magistrates, there would be no the end of liberty" 26

${ }^{23}$ Ibid., hlm. 82.

24 Ahmad Suhelmi, Pemikiran Politik

Barat, (Jakarta: Gramedia Pustaka Utama, 2001), hlm. 301 .

25 Jimly Ashidiqie, Perkembangan dan Konsolidasi Lembaga Negara Paska Amandemen, (Jakarta: Sekjen Mahkamah Konstitusi, 2006), hlm. 35 .

26 Lee Cameron McDonald, Western Political Theory, dikutip oleh Jimly Ashidiqie, dalam Perkembangan dan Konsolidasi Lembaga 
Ajaran tentang pemisahan kekuasaan yang kemudian dikenal dengan istilah trias politika tersebut memang tidak pernah dijalankan secara murni. Selalu terjadi saling-tindak antara ketiganya. Misalnya di Indonesia tidak murni tegas memisahkan kekuasaan menjadi tiga cabang kekuasaan, lebih lanjut sebagai contoh tugas hakim juga tidak hanya menjalankan hukum dan undang-undang, tetapi dalam kenyataannya para hakim juga menciptakan hukum. ${ }^{27}$

Bagan 1.2

Pemisahan Kekuasaan Tidak Murni Trias Politika

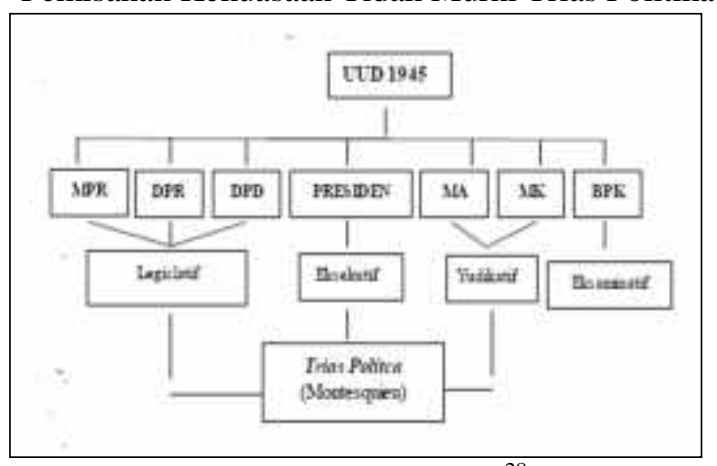

Sumber: Data Diolah ${ }^{28}$

Politik Hukum penyelesaian perselisihan hasil pemilihan Kepala Desa menurut UU Desa menyatakan bahwa penyelesaian perselisihan hasil pemilihan Kepala Desa sebagaimana disebutkan bahwa dalam hal terjadi perselisihan diselesaikan oleh Bupati/ Walikota.

\section{Pasal 37}

(6) Dalam hal terjadi perselisihan hasil pemilihan Kepala Desa, Bupati/Walikota wajib menyelesaikan perselisihan dalam jangka waktu sebagaimana dimaksud pada ayat (5).

Pengaturan demikian itu menimbulkan pertanyaan, mengapa perselisihan hasil diselesaikan oleh

Negara Paska Amandemen, (Jakarta: Sekjen Mahkamah Konstitusi, 2006), hlm. 35.

27 Arif Budiman, Teori Negara, Negara, kekuasaan dan Ideologi, (Jakarta: Gramedia 1995), hlm. 36 .

\footnotetext{
${ }^{28}$ Lihat UUD NRI Tahun 1945.
}

lembaga Bupati dan Walikota yang merupakan salah satu derivasi dari kekuasaan eksekutif, alih-alih oleh lembaga yudikatif.

Bupati/ Walikota merupakan kepala daerah di tingkat Kabupaten/ Kota. Ditinjau dari teori trias politika Bupati dan Walikota masuk kedalam cabang kekuasaan eksekutif. Kekusaan Eksekutif Bupati dan Walikota bersumber pada kekuasaan presiden sebagai kepala pemerintahan. Secara konstitusional hal ini merupakan politik hukum Pasal 1 (1) UUD NRI Tahun 1945 yang menyatakan Indonesia adalah Negara Kesatuan yang berbentuk Republik. ${ }^{29}$

Konsekuensi logis dari Indonesia sebagai Negara Kesatuan adalah keseluruhan kekuasaan bersumber dari kekuasaan pemerintah pusat. Hal ini menjadi berbeda jika Indonesia merupakan negara federal yang mana kekuasaan mulamula berasal dari negara bagian yang memberikan separuh kekuasaannya kepada pemerintah federal (teori residu).

Di Indonesia kekuasaan yudikatif atau disebut juga dengan kekuasaan kehakiman dimiliki oleh Mahkamah Agung dan Mahkamah konstitusi. ${ }^{30}$

\section{Pasal 24}

(1) Kekuasaan Kehakiman merupakan kekuasaan yang merdeka untuk menyelenggarakan peradilan guna menegakkan hukum dan keadilan.

(2) Kekuasaan kehakiman dilakukan oleh sebuah Mahkamah Agung dan badan peradilan yang berada di bawahnya dalam lingkungan peradilan umum, lingkungan peradilan agama, lingkungan peradilan militer, lingkungan peradilan tata usaha negara, dan oleh sebuah Mahkamah Konstitusi.

(3) Badan-badan lain yang fungsinya berkaitan dengan kekuasaan

${ }^{29}$ Lihat UUD NRI TAHUN 1945, Pasal 1 (1).

${ }^{30}$ Lihat UUD NRI TAHUN 1945, Pasal 24 (1), (2), dan (3). 
kehakiman diatur dalam undangundang.

Secara teoritis Kekuasaan Kehakiman dalam konteks negara Indonesia adalah kekuasaan negara yang merdeka untuk menyelenggarakan peradilan guna menekan hukum dan keadilan berdasarkan Pancasila demi terselenggarannya negara Repubik Indonesia. ${ }^{31}$ Maka dari itu cabang kekuasaan kehakiman berhak untuk memonopoli keadilan berdasarkan hukum yang berlaku. Monopoli atas keadilan ini tidak dimiliki oleh cabang kekuasaan yang lain agar terjadi check and balances diantara cabang-cabang kekuasaan.

Dengan checks and balances, dapat dihindari absolutism dari masing-masing lembaga negara, eksekutif tidak dapat menjalankan pemerintahan secara absolut, demikian pula lembaga legislatif dan lembaga yudikatif tidak terjerumus dalam kekuasaan yang secara absolut. ${ }^{32}$

Dalam sebuah negara check and balances menjadi penting agar tidak terjadi kekuasaan yang sewenang-wenang. Sebagai contoh DPR sebagai kekuasaan legislatif membentuk undang-undang untuk kemudian dilaksanakan oleh Presiden sebagai kekuasaan eksekutif, kemudian apabila dalam pelaksanaan undang-undang tersebut terjadi ketidaksesuaian pelakasanaan dengan undang-undang atau bahkan pelanggaran maka kekuasaan kehakiman yakni Mahkamah Agung dan Mahkamah konstitusi berhak untuk mengadili demi terciptanya keadilan. ${ }^{33}$

Kenyataan politik hukum penyelesaian perselisihan hasil pemilihan

31 Bambang Sutiyoso, Aspek-Aspek PengembanganKekuasaan Kehakiman di Indonesia, (Yogyakarta : UII Press, 2005), hlm. 23.

32 Anwar, Teori dan Hukum Konstitusi, (Malang: Intrans Publishing, 2011), hlm. 186-187.

33 K. Wantjik Saleh, Kehakiman dan

Peradilan, (Jakarta: SumberCahaya, 1976), hlm. 5.
Kepala Desa UU Desa yang memberikan kewenangan kepada cabang kekuasan Bupati dan Walikota tidak sejalan dengan teori trias politika yang dianut dalam tata negara Indonesia. Tentunya mekanisme kontrol (check and balances) tidak dapat dipenuhi (Pro Justicia). Hal ini dapat menimbulkan kesewenang-wenangan Bupati dan Walikota dalam menyelesaikan permasalahan hukum yang merupakan domain peradilan.

Lebih lanjut penyelesaian perselisihan hasil Pemilihan Kepala Desa juga tidak dapat dikatakan sebagai peradilan administratif, hal ini dikarenakan yang dimaksud dengan peradilan administrasi secara normative hanyalah Peradilan Tata Usaha Negara. ${ }^{34}$ Karena itu penyelesaian di Bupati atau Walikota tidaklah Pro Justicia.

Oleh karena itu perlu untuk mencari solusi bagaimana penyelesaian perselisihan hasil pemilihan Kepala Desa yang Pro Justicia. Karena pemilihan Kepala Desa bukan termasuk Rezim Pemilu, ${ }^{35}$ maka pengatura penyelesaian perselisihan yang diatur oleh rezim pemilu tidak serta merta bisa diaplikasikan pada pemilihan kepala Desa.

Terdapat dua pilihan penyelesaian.

Pertama, walaupun dalam Putusan Mahkamah Konstitusi No. 97/PUUXI/2013 ditentukan bahwa Mahkamah Konstitusi tidak lagi berwenang untuk menyelesaikan sengketa hasil pilkada langsung, Alasan utama Mahkamah Konstitusi dalam putusannya tersebut

34 SF Marbun, Peradilan Tata Usaha Negara, (Yogyakarta, 1988 Liberty), hlm. 17.

35 Pemilihan Kepala Desa tidak diamanatkan secara leterlijk oleh konstitusi. Konsekuensi logisnya, pemilihan kepala Desa juga tidak termasuk dalam rezim pemilu karena secara limitative yang disebut rezim pemilu adalah yang disebut Pasal 22E (2) : "Pemilihan umum diselenggarakan untuk memilih anggota Dewan Perwakilan Rakyat, Dewan Perwakilan Daerah, Presiden dan wakil presiden dan Dewan Perwakilan Rakyat Daerah." 
adalah bahwa Pilkada bukan merupakan rezim Pemilu, karenanya menyamakan Pilkada dengan Pemilu bertentangan dengan prinsip lex superior derogate legi inferiori. Mahkamah Konstitusi berpendapat bahwa berdasarkan Pasal 24C Ayat (1) UUD NRI Tahun 1945 ditentukan bahwa Mahkamah Konstitusi hanya diberikan kewenangan secara limitatif untuk menyelesaikan sengketa hasil Pemilu, dimana terminologi Pemilu sudah ditentukan secara limitatif di dalam Pasal 22E Ayat (2) UUD NRI Tahun 1945. Oleh karena itu, ketentuan undang-undang yang memberikan kewenangan kepada MK untuk menyelesaikan sengketa hasil Pilkada langsung bertentangan dengan UUD NRI Tahun 1945. Alasan serupa juga berlaku pada pemilihan Kepala Desa, dimana pemilihan Kepala Desa tidak rezim Pemilu yang diamanatkan Pasal 22E Ayat (2) UUD NRI Tahun 1945.

Kedua, selain Mahkamah Konstitusi, lembaga lain yang menjadi politik hukum pemerintah dalam menyelesaikan perselisihan hasil Pilkada adalah "Badan Peradilan Khusus" yang akan dibentuk. Badan Peradilan Khususn bisa dibentuk untuk menjadi solusi yuridis atas problem yuridis tertentu di tengah masyarakat, diantaranya pilkada langsung. Pasal 1 angka 8 Undang-Undang Nomor 48 Tahun 2009 menentukan bahwa "Pengadilan Khusus adalah pengadilan yang mempunyai kewenangan untuk memeriksa, mengadili dan memutus perkara tertentu yang hanya dapat dibentuk dalam salah satu lingkungan badan peradilan yang berada di bawah Mahkamah Agung yang diatur dalam undang-undang".

Lebih lanjut Pasal 27 ayat (1) Undang-Undang Nomor 48 Tahun 2009 menentukan bahwa: "Pengadilan khusus hanya dapat dibentuk dalam salah satu lingkungan peradilan yang berada di bawah Mahkamah Agung sebagaimana dimaksud dalam Pasal 25". Undang-
Undang Nomor 48 Tahun 2009 memberikan kewenangan kepada pembentuk undang-undang (open legal policy) untuk membentuk badan peradilan khusus, termasuk badan peradilan khusus yang mempunyai kewenangan untuk menyelesaikan sengketa hasil Pilkada. Badan peradilan khusus yang ditentukan dalam Pasal 157 ayat (1) Undang-Undang Nomor 8 Tahun 2015 memang Badan ini tidak disebut secara yuridis akan menangani perselisihan hasil pemilihan Kepala Desa, namun demikan berkaca dari kebebasan politik hukum pembentuk undang-undang untuk menentukan lembaga mana yang berwenang menyelesaikan perselisihan hasil Pilkada (open legal policy), ${ }^{36}$ maka perselisihan hasil pemilihan Kepala Desa juga bisa diselesaikan oleh Badan Peradilan Khusus ini selama politik hukum pembentuk undang-undang menyatakan demikian.

Tidak ada alasan untuk mendiskriminasikan pemilihan Kepala Desa, karena Desa merupakan bagian struktur pemerintahan yang diakui dalam hukum positif. Demikian seharusnya negara hukum yang menghormati asas equality before the law yang setiap orang tidak hanya harus berlaku sama dalam ketaatan hukum, tetapi juga harus diperlakukan sama oleh hukum itu sendiri, termasuk dalam hal ini masyarakat Desa dan pemilihan Kepala Desa mempunyai kedudukan yang sama di mata hukum yang seharusnya tidak ada perbedaan perlakuan antara pemilihan Kepala Desa, Pilkada, dan Pemilu yang penyeleseaian perselisihan hasilnya diselesaikan oleh lembaga peradilan.

\section{Kesimpulan}

1. Politik Hukum Pengaturan penyelesaian perselisihan hasil pemilihan Kepala Desa adalah memberikan kewenangan penyelesaian kepada Bupati dan Walikota.

${ }^{36}$ Lihat, Putusan Mahkamah Konstitusi No. 97/PUU-XI/2013. 
Pemberian kewenangan ini telah mengabaikan hak asal usul. Artinya pengaturan penyelesaian perselisihan hasil pemilihan Kepala Desa yakni diselesaikan oleh Bupati atau Walikota tidak konsisten dengan UUD NRI Tahun 1945 khususnya tidak konsisten dengan Pasal 18 B Ayat (2).

2. Politik hukum pengaturan penyelesaian perselisihan hasil pemilihan Kepala Desa menurut UU No. 6 Tahun 2014 tentang Desa tidak sesuai dengan Teori Trias Politika karena memberikan kewenangan penyelesaian hasil pemilihan Kepala Desa kepada Bupati dan Walikota yang merupakan eksekutif. Keberadaan Desa merupakan satuan pemerintahan dibawah pemerintah Kabupaten atau Kota dengan memperhatikan Hak Asal Usul. Namun perselisihan hasil pemilihan Kepala Desa di pemerintah atasannya itu bukanlah peradilan administratif, karena peradilan administrstif menurut hukum hanyalah PTUN, sehingga penyelesaian perselisihan tidak Pro Justicia. Pemilihan Kepala Desa bukan merupakan rezim Pemilu dan oleh karena itu penyelesaiannya tidak bisa dilakukan di Mahkamah Konstitusi. Solusi penyelesaian perselisihan hasil pemilihan Kepala Desa di masa depan dihadapkan dengan dua pilihan yakni oleh Mahkamah Konstitusi dengan amandemen atau Badan Peradilan Khusus dengan merubah UU No. 6 Tahun 2016 tentang Desa..

\section{Saran}

1. DPR dan Presiden agar merubah Pasal 37 ayat (6) UU No. 6 Tahun 2014 tentang Desa menjadi penyelesaian perselisihan hasil pemilihan Kepala Desa oleh lembaga peradilan, agar sesuai dengan UUD NRI Tahun 1945 dan Trias Politika. Sehingga access to justice, equality before the law dengan mendapat jaminan keadilan oleh lembaga peradilan (pro justicia).

\section{Daftar Pustaka \\ Buku:}

Arif Budiman, Teori Negara, Negara, kekuasaan dan Ideologi, Jakarta: Gramedia 1995

Anwar, Teori dan Hukum Konstitusi, Malang: Intrans Publishing, 2011

Bambang Sutiyoso, Aspek-Aspek PengembanganKekuasaan

Kehakiman di Indonesia, Yogyakarta : UII Press, 2005

Bagir Manan, Hubungan Antara Pusat dan Daerah Menurut UUD 1945, Jakarta : Sinar Harapan, 1994

Menyongsong Fajar Otonomi Daerah, Yogyakarta : Pusat Studi Hukum Fakultas Hukum UII, 2001

Charles De Montesqiue, the spirit of Laws, dalam buku Diane Revitch \& Abigail Thernstrom (ed), Demokrasi Klasik dan modern, Jakarta: Obor, 2005

Friedrich Julius Stahl, Siebzehn parlamentarische Reden und drei Vorträge : Seventeen Parliamentary Speeches and Three Lectures, Berlin: Wilhelm Hertz, 1862

Jean-Jacques Rousseau, "Du Contract Social", Terjemahan Rahayu Sutiati Hidayat dan Ida Sundari Husen, Jakarta, Dian Rakyat, 2010

Jimly Asshiddiqie, Perkembangan dan Konsolidasi Lembaga Negara Pasca Reformasi, Jakarta: Sinar Grafika, 2010

\section{Pokok-pokok Hukum}

Tata Negara, Jakarta: PT Bhuana Ilmu Populer, 2008

, Pengantar Ilmu Hukum

Tata Negara, Jakarta: Rajawali Pers, 2013

Konsep Negara Hukum,

Tanpa Tempat: Majalah Hukum Indonesia, Tanpa Tahun

Kaelan, Pendidikan Kewarganegaraan Untuk Perguruan Tinggi, 
Yogyakarta: Paradigma, 2010

K. Wantjik Saleh, Kehakiman dan

Peradilan, Jakarta: SumberCahaya, 1976

Lee Cameron McDonald, Western

Political Theory, dikutip oleh Jimly Ashidiqie, dalam Perkembangan dan Konsolidasi Lembaga Negara Paska Amandemen, Jakarta: Sekjen Mahkamah Konstitusi, 2006.

Mahfud MD, Hukum dan Pilar-pilar

Demokrasi, Yogyakarta: Gama Media, 1999

Muhammad As Hikam, Civil Society, Negara, dan Gerakan Kaum Muda, pengantar dalam buku Menuju Masyarakt Madani, Anas Urbaningrum, Jakarta: Penerbit Yarsif Watampone, 1997

Ni'matul Huda, Hukum Pemerintahan

Desa, Malang: Setara Press, 2015

Sujamto, Daerah Istimewa Dalam Negara Kesatuan Republik Indonesia, Jakarta : Bina Aksara, 1984

SF Marbun, Peradilan Tata Usaha Negara, Yogyakarta, 1988 Liberty

Widayati, Rekonstruksi Kedudukan TAP MPR Dalam Sistem

Ketatanegaraan, Yogyakarta: Genta Publishing, 2015.

\section{Jurnal dan Karya Ilmiah}

Anotasi Undang-Undang No.6 Tahun 2014 tentang Desa, Jakarta: Sekjen DPR, 2014

\section{Peraturan Perundang-Undangan}

UUD Negara Kesatuan Republik Indonesia Tahun 1945

Undang-Undang No. 22 Tahun 1999 Tentang Pemerintahan Daerah. Lembaran Negara Republik Indonesia Tahun 1999 Nomor 60

Undang-Undang Nomor 32 Tahun 2004 Tentang Pemerintahan Daerah.
Lembaran Negara Republik Indonesia Tahun 2004 Nomor 125. Tambahan Lembaran Negara Republik Indonesia Nomor 4437

Undang-Undang No. 48 tahun 2009 tentang Kekuasaan Kehakiman. Lembaran Negara Republik Indonesia Tahun 2009 Nomor 157.

Undang-Undang No. 6 Tahun 2014 tentang Desa. Lembaran Negara Republik Indonesia Tahun 2014 Nomor 7. Tambahan Lembaran Negara Nomor 5495

Undang-Undang No. 1 Tahun 2015 tentang Penetapan Peraturan Pemerintah Pengganti Undang-Undang Nomor 1 Tahun 2014 Tentang Pemilihan Gubernur, Bupati, Dan Walikota Menjadi Undang-Undang sebagaimana telah diubah dengan UU No. 10 Tahun 2016. Lembaran Negara Republik Indonesia Tahun 2014 Nomor 245. Tambahan Lembaran Negara Republik Indonesia Nomor 5588

Undang-Undang No. 7 tahun 2017 tentang Pemilihan Umum. Lembaran Negara Republik Indonesia Tahun 2017 Nomor 182. Tambahan Lembaran Negara Republik Indonesia Nomor 6109

Peraturan Menteri Dalam Negeri No. 112 Tahun 2014 tentang Pemilihan Kepala Desa

Putusan Mahkamah Konstitusi No. 6/PUUVI/2008

Putusan Mahkamah Konstitusi No. 97/PUU-XI/2013 